\title{
REVIEW I Vaudeville Melodies: Popular Musicians and Mass Entertainment in American Culture, 1870-1929
}

\author{
Nicholas Gebhardt \\ ISBN: 9780226448695 (PB)

\section{Derek B. Scott} \\ University of Leeds \\ d.scott@leeds.ac.uk
}

Chicago: University of Chicago Press, 2017

Nicholas Gebhardt's book, as a whole, is designed to offer a study of transformations in American popular culture that came about as a consequence of the growth in power and sophistication of the entertainment business. Gebhardt's arguments are bolstered by informed use of theory and he draws his supporting evidence from both primary and secondary sources. The period chosen is one in which some commentators speak of the industrialization of culture, and American vaudeville provides an effective focal point for such an argument. The marketing of the songs of Tin Pan Alley had already shown the profits to be gained by adopting business strategies, and it was this music that both fed the needs of vaudeville, and was, in turn, stimulated by vaudeville. The study stretches from pioneering figures such as Tony Pastor and Bert Williams, through to the big stars of the 1920s, such as Sophie Tucker and Harry Houdini. This means that the book, although an indisputably academic work, will have appeal beyond the specialist historian.

The two best-known competing books are Albert McLean, American Vaudeville as Ritual (1965) and John DiMeglio, Vaudeville U.S.A. (1973). Both of these texts are now showing their age, and Gebhardt discusses them and makes clear his own distinctive positioning in his introduction. There are two more recent books (Kibler 1999 and Snyder 2000), as well as a number of scholarly chapters and articles on vaudeville, but Gebhardt is aware of their arguments also, which often concern cultural power, contested meanings, identity, ethnicity and social class. The distinctness of the present book is found in its emphasis on actual practice on the vaudeville stage, and in its account of the experiences of the musicians who performed there. It continually raises questions about the way in which vaudeville artists develop and understand the skill of entertaining an audience.

The chapters cover all the important ground for a study focusing on practice. Chapter Two examines touring and the theatrical circuits, discussing the impact of 
the Syndicate-run theatres, and the changes brought about by the buying up of groups of theatres. It also considers the need to appeal to varied audiences, and the topicality of humour: comedians need to know if their jokes will go down as well in Boston as Chicago. Chapter Three examines what Gebhardt calls vaudeville rituals, interestingly illustrated with a case study of Sophie Tucker's on-stage dramatization of certain banal aspects of her personal life (which became significant to her popularity). Chapters Four and Five examine the rise of show business ideology: the earlier chapter contains discussions of show business families, and the conflict of backstage and frontstage presentation of self; and the following chapter examines the corporate-capitalist aspects of the business, while never losing sight of the link between vaudeville and its audience - an example being the profits to be made from a family audience. Mixed with interesting details about individual practice, Chapter Six brings home the cultural reasons why vaudeville is important, despite the neglect or scorn shown by some academics (although not by recent scholars).

Chapter Seven shifts to the relationship between artists and audiences, and once more emphasizes the necessity of attuning an act to different audiences. The next two chapters contain valuable and insightful coverage of the music of vaudeville, its production, appeal, and cultural value, but they also recapitulate some previous topics such as the way performers understood their success, and the way popular entertainment intersected with performers' lives. The final chapter addresses the multiplicity of vaudeville practice and digs into its cultural values and meanings. Perhaps Gebhardt's boldest claim is that vaudeville opened up a heterogeneous space where artistic distinctions were questioned at the same time as they were being transformed. However, this is a solid conclusion supported by the evidence that he has amassed and the persuasive arguments that he has developed. It is also something that can now be thrown in the face of any lingering claims that vaudeville was merely the mind-numbing fodder of a manipulative cultural industry. This book is essential reading not only for its exploration of practice, but also for its focus on how this business was shaped and changed by the circuits, the stress on respectable family entertainment, its star system, and the continuous show that was vaudeville.

\section{References}

DiMeglio, J., 1973. Vaudeville U.S.A. Bowling Green, OH: Bowling Green University Popular Press.

Kibler, M. A., 1999. Rank Ladies: Gender and Cultural Hierarchy in American Vaudeville. Chapel Hill, NC: University of North Carolina Press.

McLean, A., 1965. American Vaudeville as Ritual. Lexington, KY: University of Kentucky Press.

Snyder, R. W., 2000. The Voice of the City: Vaudeville and Popular Culture in New York. Chicago: Ivan R. Dee. 1st pub. New York: Oxford University Press, 1989. 